Vol 1. No 1. Agustus 2021, e-ISSN : 2807-1670 | p-ISSN : 2807-2316

\title{
IMPLEMENTASI JAZZ CHANTS VIDEO DALAM MENINGKATKAN PENGUASAAN KOSA KATA BAHASA INGGIRIS DI ABA DIAN CIPTA CENDIKA
}

\author{
NILA SARI DEWI \\ ABA Dian Cipta Cendikia \\ e-mail : indigoieg@yahoo.co.id
}

\begin{abstract}
ABSTRAK
Penelitian ini bertujuan untuk mendeskripsikan proses pembelajaran kosa kata Bahasa Inggris menggunakan media Jazz Chants video, dan. peningkatan penguasaan kosa kata Bahasa Inggris mahasiswa. Jenis penelitian ini adalah penelitian tindakan kelas dengan melibatkan mahasiswa Akademi Bahasa Asing Dian Cipta Cendikia Bandar Lampung pada kelas D3-BI-IA dan D3BI-IB tahun pembelajaran 2020-2021. Penelitian tindakan ini dilakukan dalam dua siklus. Pada siklus I, tindakan dilakukan berupa menyimak Jazz Chants dalam bentuk audio, membaca teks lagu, pemahaman arti kata, dan mencari fungsi kata dalam kalimat. Pada siklus II, aktivitas pembelajaran dikembangkan dengan menyimak dan mengisi rumpang yang kosong (cloze procedure), membaca teks Jazz Chants dalam bentuk audio visual, pemahaman makna kalimat dalam teks lagu, mengucapkan kalimat dan menceritakan kembali isi lagu. Instrumen penelitian yang digunakan adalah observasi dan tes. Hasil penelitian menunjukkan bahwa (1).adanya peningkatan jumlah mahasiswa yang aktif dalam pembelajaran, yaitu; kelas D3-BI-IB, dalam siklus I, pada pertemuan 1 berjumlah 12 orang atau sebesar $60 \%$ dan pertemuan 2 berjumlah 14 orang atau $70 \%$ dan siklus II, pada pertemuan I berjumlah 15 orang atau sebesar $75 \%$ dan pertemuan 2 berjumlah 18 orang atau 90\%. Sedangkan kelas D3-BI-IB , dalam siklus I pada pertemuan I berjumlah 10 orang atau sebesar 50\%, dan pertemuan 2 berjumlah 13 orang atau $65 \%$ dan siklus II, pertemuan I berjumlah 16 orang atau sebesar $80 \%$ dan pertemuan 2 berjumlah 17 orang atau sebesar $85 \%$, dan (2) hasil prestasi belajar pada tes penguasaan I menunjukkan bahwa kelas D3-BI-IA jumlah mahasiswa yang tuntas 11 orang atau sebesar 55\% dan kelas D3-BI-IB juga berjumlah 11 orang atau 55\%. Data yang diperoleh dari hasil prestasi belajar pada Tes Penguasaan II, mahasiswa yang tuntas pada kelas D3-BI-IA berjumlah 18 orang atau sebesar $90 \%$ dan kelas D3-BI-IB berjumlah 16 orang atau $80 \%$.
\end{abstract}

Kata kunci : Jazz Chants, peningkatan, penguasaan kosa kata

\section{PENDAHULUAN}

Bahasa merupakan alat komunikasi yang sangat penting untuk mentrasfer dan mengadaptasikan berbagai budaya, ilmu pengetahuan serta teknologi-teknologi baru yang perlu diinformasikan diskala internasional. Bahasa Inggris sebagai suatu bahasa yang digunakan dalam masyarakat global dapat dipergunakan sebagai media komunikasi dengan orang lain dari berbagai negara. Selain itu, dengan menguasai bahasa Inggris maka orang akan dengan mudah masuk dan dapat mengakses dunia informasi dan teknologi. Menurut Huda (1999:405), "bahasa sebagai alat berkomunikasi. Penguasaan bahasa asing menjadi salah satu modal utama keunggulan kompetitif dan oleh sebab itu penguasaan bahasa asing menjadi salah satu ciri sumber daya manusia yang berkualitas." Berdasarkan pernyataan ini, Bahasa Inggris adalah media komunikasi yang digunakan sebagai bahasa internasional dan juga merupakan bahasa asing pertama di Indonesia.

Berkenaan dengan pernyataan di atas, pengalaman pembelajaran di ABA (Akademi Bahasa Asing) DCC (Dian Cipta Cendikia) masih terdapat permasalahan pembelajaran pada penguasaan kosa kata mahasiswa yang masih rendah khususnya pada tahun pertama proses perkuliahan. Permasalahan lemahnya kosa kata Bahasa Inggris pada mahasiswa pemula dapat dilihat dari proporsi mahasiswa pada tahun pertama yang memperoleh nilai A (sangat baik) pada Mata Kuliah Vocabulary Building masih rendah, hal ini dapat di lihat dari Tabel 1.1 
LANGUAGE : Jurnal Inovasi Pendidikan Bahasa dan Sastra

Vol 1. No 1. Agustus 2021, e-ISSN : 2807-1670 | p-ISSN : 2807-2316

Tabel 1. Proporsi mahasiswa menurut sebaran nilai yang dicapai pada Mata Kuliah Vocabulary Building

\begin{tabular}{|c|c|c|c|c|c|c|c|}
\hline \multirow{2}{*}{$\begin{array}{l}\mathbf{N} \\
\mathbf{0}\end{array}$} & \multirow{2}{*}{ Kelas } & \multicolumn{5}{|c|}{ Nilai } & \multirow{2}{*}{$\begin{array}{c}\text { Jumla } \\
\text { h }\end{array}$} \\
\hline & & $\mathbf{A}$ & B & $\mathrm{C}$ & D & $\mathbf{E}$ & \\
\hline \multirow{3}{*}{1} & D3-BI-A & & & & & & \\
\hline & $\begin{array}{l}\text { Vocabulary } \\
\text { Building I }\end{array}$ & $0 \%$ & $16 \%$ & $60 \%$ & $20 \%$ & $4 \%$ & $100 \%$ \\
\hline & $\begin{array}{l}\text { Vocabulary } \\
\text { Building II }\end{array}$ & $4.3 \%$ & $56.5 \%$ & $17.4 \%$ & $13,1 \%$ & $8.7 \%$ & $100 \%$ \\
\hline \multicolumn{2}{|c|}{$\begin{array}{l}\text { Jumlah } \\
\text { Rata/Tahun }\end{array}$} & $\begin{array}{l}2.15 \\
\%\end{array}$ & $36.25 \%$ & $38.7 \%$ & $\begin{array}{c}16.55 \\
\%\end{array}$ & $6.35 \%$ & $100 \%$ \\
\hline \multicolumn{8}{|c|}{ D3-BI-B } \\
\hline \multirow[t]{2}{*}{2} & $\begin{array}{l}\text { Vocabulary } \\
\text { Building I }\end{array}$ & $12 \%$ & $16 \%$ & $24 \%$ & $24 \%$ & $24 \%$ & $100 \%$ \\
\hline & $\begin{array}{l}\text { Vocabulary } \\
\text { Building II }\end{array}$ & $4.16 \%$ & $12.55 \%$ & $33.3 \%$ & $29.16 \%$ & $20.83 \%$ & $100 \%$ \\
\hline \multicolumn{2}{|c|}{$\begin{array}{l}\text { Jumlah Rata } \\
\text { Rata/Tahun }\end{array}$} & $\begin{array}{l}8.08 \\
\%\end{array}$ & $\begin{array}{c}14.275 \\
\%\end{array}$ & $\begin{array}{c}28.65 \\
\%\end{array}$ & $\begin{array}{c}26.58 \\
\%\end{array}$ & $\begin{array}{c}22.415 \\
\%\end{array}$ & $100 \%$ \\
\hline \multicolumn{2}{|c|}{$\begin{array}{l}\text { Rata-Rata } \\
\text { Keseluruhan }\end{array}$} & $\begin{array}{c}5,11 \\
\%\end{array}$ & $25,26 \%$ & $\begin{array}{c}33,67 \\
\%\end{array}$ & $\begin{array}{c}21,56 \\
\%\end{array}$ & $14,38 \%$ & $100 \%$ \\
\hline
\end{tabular}

Berdasarkan data di atas, hal ini dapat dijelaskan bahwa pada Mata Kuliah Vocabulary Building pada tahun pertama kelas D3-BI A dan D3-BI-B yang keseluruhan berjumlah 40 orang, yang mendapatkan nilai A sebesar 5,11\%, nilai B sebesar $25,26 \%$, nilai C sebesar $33,67 \%$, nilai D 21,56\% dan nilai E sebesar 14,38\%. Data tersebut diperoleh dari nilai akhir mahasiswa selama perkuliahan berlangsung untuk dua semester dalam periode tahun 20202021. Data tersebut menunjukkan kualitas penguasaan kosa kata Bahasa Inggris belum memuaskan dengan persentasi nilai tertinggi adalah $\mathrm{C}$ (cukup) dan belum mencapai indikator ketuntasan 61 untuk keberhasilan pembelajaran 70-80\% dari proporsi jumlah mahasiswa dalam satu kelas menurut prosentase penilaian dari bidang akademik ABA DCC Bandar Lampung.

Selain data di atas, pembelajaran vocabulary masih cenderung berpusat pada dosen dengan penggunaan metode konvensional, dan juga mahasiswa cenderung tidak memberikan perhatian yang cukup pada pembelajaran kosa kata, seperti mereka sulit dalam penguasaan kosa kata (memory), masih adanya kesalahan dalam pengucapan (pronunciation), dan strategi pembelajaran yang mereka peroleh kurang bervariasi hanya mengandalkan buku panduan pembelajaran..

Dengan adanya permasalahan tersebut, maka dipandang perlu adanya perubahan pembelajaran lama yang terfokus pada guru (teacher-centered) menjadi pembelajaran yang terpusat pada aktivitas mahasiswa (students-centered) melalui proses pembelajaran Bahasa Inggris yang berkualitas dengan keterpaduan teori dan media pembelajaran yang sesuai dengan kebutuhan siswa. Menurut Sadiman (1993:6), "proses belajar mengajar pada hakikatnya adalah proses komunikasi. Proses komunikasi yaitu proses menyampaian pesan dari sumber pesan melalui saluran atau media tertentu kepada penerima pesan, pesan - pesan tersebut berupa isi ajaran yang ada di kurikulum dituangkan oleh guru atau sumber lain ke dalam simbol - simbol komunikasi visual maupun verbal." Berdasarkan penyataan ini, pada hakikatnya proses belajar mengajar merupakan sebuah sistem, yang di dalamnya memiliki berbagai komponen yang saling bekerja sama dan terpadu untuk mencapai tujuan pembelajaran. Komponen - komponen tersebut adalah tujuan pengajaran, guru dan peserta didik, bahan pelajaran, metode dan strategi belajar mengajar, alat atau media, sumber pelajaran dan evaluasi.

Media pembelajaran merupakan salah satu komponen pembelajaran yang mempunyai peranan penting dalam proses pembelajaran. Sadiman (1993:1) menyatakan, "Media adalah alat atau sarana yang dapat digunakaan untuk menjelaskan sesuatu." Pemanfaatan media 
seharusnya merupakan bagian yang harus mendapat perhatian dosen sebagai fasilitator dalam setiap kegiatan pembelajaran. Oleh karena itu dosen perlu mempelajari bagaimana menetapkan media pembelajaran agar dapat mengefektifkan pencapaian tujuan pembelajaran dalam proses belajar mengajar. Media pembelajaran lazim disebut sebagai alat-alat belajar. Metode yang tepat untuk bahan pelajaran tertentu dapat lebih efektif jika disertai dengan media pembelajaran yang tepat pula yang sesuai dengan perkembangan mahasiswa sebagai peserta didik. Pemanfaatan media pembelajaran dalam proses pembelajaran dapat membangkitkan keinginan dan minat yang baru, membangkitkan motivasi dan rangsangan kegiatan belajar dan bahkan membawa pengaruh psikologis terhadap mahasiswa. Penggunaan media pembelajaran pada tahap orientasi pembelajaran akan sangat membantu keefektifan proses pembelajaran dan penyampaian pesan dan materi pembelajaran. Selain membangkitkan motivasi dan minat mahasiswa, media pembelajaran juga dapat membantu mahasiswa meningkatkan pemahaman, menyajikan data menarik dan terpercaya, memudahkan penafsiran data, dan memadatkan informasi. Dosen dapat memberikan materi pembelajaran yang bersifat audio, visual, audiovisual dan multimedia, maka salah satu media yang digunakan untuk mendukung model pembelajaran yaitu lagu-lagu berbahasa Inggris.

Belajar kosa kata dengan media lagu dapat dimanfaatkan untuk menciptakan suasana yang menyenangkan selama pembelajaran, menimbulkan minat dan semangat belajar siswa. Siswa tipe musik "Auditory learners" lebih cocok mempelajari materi yang dikemas dalam bentuk musik. Hal ini mendukung pernyataan yang dipaparkan Papa dan Lantoro (1979:viii) bahwa "introducing song in the classroom can solve most of the problems concerning motivation.. singing a song is one activities which geneerate enthusiasm and pleasant and stimulating approach to culture of foreign language". Pernyataan ini didukung oleh Yunanto (2010), "Jika siswa merupakan individu yang lebih mudah belajar dengan mendengarkan, maka siswa tersebut bisa memperbanyak porsi belajar dengan mendengarkan, misalnya mendengarkan kaset-kaset pelajaran Bahasa Inggris, lagu-lagu favoritnya dalam bahasa Inggris". Berdasarkan pernyataan ini, disamping dapat pula dijadikan media pembelajaran kosakata, pengucapan syair Bahasa Inggris sebagai alat untuk membetulkan ucapan yang salah tanpa menimbulkan rasa malu dipihak siswa yang belajar untuk penguasaan kosa kata Bahasa Inggris.

Jazz chants diperkenalkan oleh Carolyn Graham, professor dari Universitas New York, sekitar tahun 1970an. Menurut Graham, jazz chant adalah ritme ekspresi berbicara Bahasa Inggris. Melakukan Jazz Chant pada belajar kosa kata Bahasa Inggris sangat mudah untuk diikuti dan dipahami berdasarkan irama lagu. Zhang (2011) menyatakan " Jazz Chant is a rhythmic expression of natural language which links the rhythms of spoken American English to the rhythms of traditional American jazz”. Jadi formula dari ritme, intonasi dan tekanan pada Jazz Chant sebagai bahasa dari native speaker dalam bentuk percakapan atau formula Berbahasa Inggris.Medonna (1993) berpendapat bahwa "music has strong effect on second language vocabulary acquisition". Pernyataan ini menunjukkan bahwa adanya peningkatan penguasaan kosa kata yang diperoleh siswa secara tidak langsung saat menggunakan media musik atau lagu yang berisi teks Bahasa Inggris dalam pembelajaran. Hal ini didukung oleh Salwa (2016) dalam penelitiannya menunjukkan bahwa. " most of the students (85\%) have positive attitudes towards the use of songs as considerable media to help them understand the meanings of figurative language and improve their motivation in learning English". Sedangkan, Pusporini (2012) berpendapat bahwa lagu memiliki pengaruh positif terhadap pengayaan kosa kata siswa ketika mereka belajar bahasa asing secara alami. Berdasarkan uraian tersebut, Bahasa Inggris yang sekarang ini sebagai bahasa internasional, sangat penting sekali untuk dikuasai. Hal yang mendasar dalam mempelajari Bahasa Inggris adalah tentang penguasaan kosakata, maka seorang pengajar harus bisa memilih media pembelajaran yang tepat dan efisien untuk meningkatkan mahasiswa yang aktif dalam pembelajaran dan penguasaan kosa kata Bahasa Inggris. 
Penelitian ini bertujuan untuk mendeskripsikan proses pembelajaran vocabulary melalui penggunaan lagu berbahasa Inggris dalam meningkatkan keaktifan mahasiswa dalam aktivitas pembelajaran dan peningkatan penguasaan kosa kata mahasiswa dalam pembelajaran kosa kata dengan menggunakan media lagu.

\section{METODE PENELITIAN}

Penelitian ini merupakan Penelitian Tindakan Kelas (Classroom Action Research), yaitu upaya guru atau praktisi dalam bentuk berbagai kegiatan yang dilakukan untuk meningkatkan mutu pembelajaran siswa dan diharapkan dapat memperbaiki masalah-masalah yang ada di dalam kelas. Pemilihan jenis penelitian ini dimaksudkan untuk memperbaiki proses pembelajaran bahasa Inggris terhadap peningkatan penguasaan kosa kata khususnya pada mata kuliah Vocabulary Building di Perguruang Tinggi ABA DCC Bandar Lampung.

Penelitian dilakukan di Akademi Bahasa Asing (ABA) Dian Cipta Cendikia (DCC) Bandar Lampung. Pada mahasiswa semester I kelas D3-BI-IA dan D3-BI-IB yang masingmasing kelas berjumlah 20 orang. Penelitian ini dilakukan dengan menyesuaikan kalender akademik ABA DCC Bandar Lampung yaitu semester genap periode 2020/2021 pada bulan Februari-Juli 2021.

Penelitian ini dilakukan pada mahasiswa program studi Bahasa Inggris. Penelitian berlangsung selama satu semester. Subjek penelitian ini adalah mahasiswa semester tiga tahun akademik 2020/2021 yaitu kelas D3-BI-IA dan D3-BI-IB dimana masing-masing kelas berjumlah 20 mahasiswa di ABA DCC Bandar Lampung. Instrumen penelitian yang digunakan adalah observasi dan tes.

\section{HASIL DAN PEMBAHASAN}

\section{Hasil}

Penelitian tindakan kelas dilaksanakan dalam dua siklus. Siklus I dilaksanakan dalam tiga kali pertemuan dengan alokasi waktu 90 menit dalam satu kali pertemuan dan siklus II juga dilaksanakan dalam tiga kali pertemuan dengan alokasi waktu 90 menit untuk satu kali pertemuan. Hasil penelitian yang disajikan dalam bab ini meliputi hasil siklus I dan II, data observasi mahasiswa dan observasi dosen pada tindakan siklus I dan siklus II, dan hasil peningkatan prestasi belajar siklus I dan II.

\section{A. Siklus I}

Kondisi awal Sebelum penelitian tindakan kelas, pembelajaran bahasa Inggris yang dilakukan dikelas D3-BI-IA dan D3-BI-IB ABA DCC Bandar Lampung, hanya bersifat verbalistik artinya dengan menggunakan strategi ceramah saja dan menggunakan buku panduan, tanpa media yang bervariasi. Minimnya penguasaan bahasa Inggris sebagai pengantar dalam pembelajaran maupun diluar proses pembelajaran, karena kurang diterapkannya metode dan teknik pengajaran yang bervariasi dan menstimulus keaktifan mahasiswa dalam pembelajaran, kurangnya memberikan kesempatan kepada mahasiswa untuk mengembangkan kreatifitasnya didalam pembelajaran, dosen belum menyajikan pembelajaran Bahasa Inggris secara integral, misalnya dosen hanya berorientasi pada tuntasnya materi pelajaran, tanpa memperhatikan penguasaan yang diperoleh peserta didik, mahasiswa hanya berasumsi bahwa yang penting hasil ujiannya bernilai baik.

Pada siklus I terdiri dari 3 tindakan dengan materi Nouns, Verbs, Adjective dan Adverbs. Tindakan ini mendengarkan kosa kata (listening), menuliskan kosa kata (writing), membaca teks (reading), melatih ingatan (memory), pemahaman (meaning), serta pengucapan (pronunciation) dan melatih kosa kata dalam kalimat bebas atau menceritakan kembali isi teks (speaking). 


\section{Tahap Pengamatan}

\section{A. Hasil Instrumen Observasi Dosen}

Dalam pelaksanaan observasi, peneliti mengundang dua orang dosen sebagai kolaborator. Salah satu kolaborator bertugas mengobservasi kegiatan pembelajaran dosen, dan kolaborator yang lain bertugas mengamati kegiatan pembelajaran mahasiswa. Observasi dilakukan oleh dua anggota peneliti dan perekaman data dilakukan dengan checklist.

Pada siklus I terdiri dari 3 tindakan. Hal ini berarti telah dilakukan 3 kali pengamatan. Tindakan dibagi menjadi tiga tahapan, yaitu : 1) Tahap awal kegiatan pembelajaran (preactivity), tahap selama proses pembelajaran (while-activity) dan tahap akhir kegiatan (postactivity). Indikator untuk observasi dosen meliputi: 1). Membuka pembelajaran dengan memberi salam, 2). Menjelaskan langkah-langkah pembelajaran, 3). Memberi motivasi, 4). Memperkenalkan media lagu, 5). Melatih pengucapan, 6). Memantau kegiatan siswa, 7). Memberi bantuan kepada mahasiswa, 8). Menjelaskan materi pembelajaran, 9). Memberi kesempatan siswa bertanya, 10) Melatih mahasiswa mencari kata-kata dalam teks lagu yang berkaitan dengan materi pembelajaran, 11). Membahas hasil kerja, 12). Melatih mahasiswa untuk membuat kalimat bebas, 13). Memberi kesimpulan pembelajaran. Keseluruhan hasil pengamatan kemudian dianalisis dan didiskusikan dengan teman kolaborasi untuk menentukan langkah perbaikan pada siklus selanjutnya.

\section{B. Instrumen Observasi Mahasiswa}

Instrumen observasi siswa sebagai data untuk mengetahui peningkatan penguasaan kosa kata siswa secara akurat selama proses pembelajaran berlangsung. Dosen dan kolaborator dapat mengamati mahasiswa yang aktif dan tidak aktif dalam tahapan pembelajaran di kelas. Untuk menyajikan data dari hasil pengamatan terhadap pelaksanaan tindakan kelas.

Pada siklus I, proses pembelajaran untuk penguasaan kosa kata bahasa Inggris terfokus pada kata dan cara pengucapan yang baik, hanya saja mahasiswa belum semua aktif mengikuti semua proses pembelajaran seperti mereka masih enggan untuk menjawab pertanyaan dosen dan malu bertanya, serta masih sulit untuk mengimprovisasikan kata-kata tersebut dalam kalimat sendiri. Data yang diperoleh pada siklus I mengenai jumlah mahasiswa yang aktif selama aktivitas pembelajaran pada pertemuan I untuk kelas D3-BI-IA sebanyak 12 orang dan kelas D3-BI-IB sebanyak 10 orang, sedangkan pada pertem,uan II untuk kelas D3-BI-IA sebanyak 14 orang dan kelas D3-BI-IB sebanyak 13 orang (lihat pada lampiran 6). Hasil prosentase keaktifan mahasiswa tindakan siklus I dapat diperlihatkan pada tabel sebagai berikut

Tabel 2. Prosentase Keaktifan Siswa Tindakan Siklus I (\%)

\begin{tabular}{|c|c|c|}
\hline Kelas & Pertemuan I & Pertemuan II \\
\hline D3-BI-IA & $\mathbf{6 0 \%}$ & $\mathbf{7 0 \%}$ \\
\hline D3-BI-IB & $\mathbf{5 0 \%}$ & $\mathbf{6 5 \%}$ \\
\hline
\end{tabular}

\section{Tahap Refleksi}

Pada akhir pertemuan tindakan siklus I, mahasiswa diberikan evaluasi pembelajaran melalui pemberian tes soal pilihan ganda (multiple choice) dengan tujuan untuk mengetahui peningkatan penguasaan kosa kata bahasa Inggris siswa setelah mereka mengalami pembelajaran kosa kata melalui pengguinaan media lagu. Data yang diperoleh dari hasil tes penguasaan I menunjukkan bahwa pada kelas D3-BI-IA jumlah mahasiswa yang tuntas 11 orang atau sebesar 55\% dan pada kelas D3-BI-IB juga berjumlah 11 orang atau sebesar 55\%. Hal ini berarti hasil prestasi belajar belum mencapai indikator ketuntasan $70 \%$.

Setelah dilakukan tes, maka tes tersebut dievaluasi melalui program analisis soal. Setelah nilai tiap individu didapat, diberi nilai dan ditabelkan, lalu dimasukkan dalam rumus yang telah terprogram dalam program analisis soal, maka hasil data yang diperoleh dari evaluasi pada tindakan siklus I, sebagai berikut: 
1) Hasil Validitas butir $r$ tabel sebesar 0,312 , dengan butir soal yang valid berjumlah 31 butir dan tidak valid berjumlah 19 butir.

2) Hasil Reliabilitas tes sebesar 0,859 (menurut KR-20) dengan kategori reliabilitas sangat tinggi.

3) Hasil Tingkat Kesukaran dan Daya Beda diperoleh data 30 soal sangat baik (soal diterima), 3 soal cukup dan 17 soal jelek (soal ditolak).

Dari data yang diperoleh, dan setelah data dianalisis, hasilnya menggambarkan tindakan siklus I sebagai berikut:

1. Jumlah mahasiswa yang aktif dalam pembelajaran belum mencapai $75 \%$ selama proses pembelajaran.

2. Tes penguasaan I telah dievaluasi berdasarkan keempat komponen evaluasi pembelajaran menggunakan program SIMPEL PAS. Reliabilitas, validitas dan tingkat kesukaran dan daya beda telah mencapai indikator keberhasilan.

3. Peningkatan penguasaan kosa kata Bahasa Inggris mahasiswa dari hasil prestasi belajar belum mencapai indikator keberhasilan $70 \%$.

Dari hasil tindakan siklus I di atas, maka peneliti perlu melakukan tindakan siklus II untuk mencapai tujuan pembelajaran dan indikator keberhasilan dengan rekomendasi perbaikan siklus II, sebagai berikut:

1. Pada SAP ditambahkan aktivitas pembelajaran pada tahap selama kegiatan (whileactivity) untuk melatih penguasaan kosa kata seperti latihan mendengarkan teks lagu (listening), menuliskan kata-kata pada teks lagu (writing), membaca teks lagu (reading), melatih pengucapan (pronunciation), memahami arti kata (meaning), membuat kalimat, dan menceritakan isi teks lagu (speaking) berdasarkan kemampuan penguasan kosa kata mahasiswa. Sedangkan media lagu untuk pembelajaran diubah dalam bentuk audio visual

2. Perbaikan pada aktivitas proses pembelajaran melalui penambahan kegiatan yang tertera pada SAP agar pembelajaran komprehensif pada penguasaan kosa kata dan untuk meningkatkan jumlah mahasiswa yang aktif hendaknya dosen dapat lebih mengawasi dan membantu mahasiswa yang menemukan kesulitan selama proses pembelajaran.

3. Sistem evaluasi belum semua komponen mencapai ketuntasan. Pada siklus II diberikan Tes Penguasaan II, maka soal tes dan hasil nilai mahasiswa dievaluasi kembali melalui program SIMPEL PAS.

4. Untuk meningkatkan penguasaan kosa kata mahasiswa, materi tes hendaknya berhubungan dengan materi yang telah mereka pelajari selama proses pembelajaran.

\section{Siklus II}

\section{Tahap Perencanaan}

Berdasarkan hasil tindakan siklus I, ada beberapa indikator yang belum tercapai dan proses pembelajaran yang belum komprehensif, maka peneliti mempersiapkan hal-hal yang berkaitan dengan administrasi mengajar untuk tindakan siklus II, yaitu: Satuan Acara Perkuliahan, lembar observasi mahasiswa dan dosen, soal tes penguasaan, dan media lagu-lagu Jazz. Chants dalam bentuk audio visual yang didownload dari http://www.youtube.com/ dan/atau dibuat melalui program Vegas 7 ,

Pada siklus II ini adalah pengembangan perencanaan yang telah disusun pada siklus I untuk menambah latihan (practice) penguasaan kosa kata dengan aktivitas yang lebih beragam.

\section{Tahap Pengamatan}

\section{A. Hasil Instrumen Observasi Dosen}

Dalam pelaksanaan observasi, seperti pada tindakan siklus I, peneliti juga mengundang dua orang dosen sebagai kolaborator. Salah satu kolaborator bertugas mengobservasi kegiatan pembelajaran dosen, dan kolaborator yang lain bertugas mengamati kegiatan pembelajaran 
mahasiswa. Pada siklus II terdiri dari 3 tindakan. Hal ini berarti telah dilakukan 3 kali pengamatan. Tindakan dibagi menjadi tiga tahapan, yaitu : 1) Tahap awal kegiatan pembelajaran (pre-activity), tahap selama proses pembelajaran (while-activity) dan tahap akhir kegiatan (post-activity). Keseluruhan hasil pengamatan kemudian dianalisis dan didiskusikan dengan teman kolaborasi untuk menentukan langkah perbaikan pada siklus selanjutnya.

\section{B. Hasil Instrumen Observasi Mahasiswa}

Pada siklus II, proses pembelajaran untuk penguasaan kosa kata bahasa Inggris terfokus pada kata dan cara pengucapan yang baik, serta latihan mengekspresikan penguasaan kosa kata kedalam kalimat bebas dan atau menceritakan kembali isi teks lagu per paragraf. Mahasiswa tampak aktif mengikuti semua proses pembelajaran sebagai contoh mereka dapat mengimprovisasikan kata-kata tersebut dalam kalimat sendiri.

Data yang dipeoleh dari hasil pengamatan terhadap pelaksanaan tindakan kelas yaitu, kelas D3-BI-IA, mahasiswa yang aktif pada pertemuan I berjumlah 15 orang dan pada pertemuan II berjumlah 18 orang, dan kelas D3-BI-IB, mahasiswa yang aktif pada pertemuan I berjumlah 16 orang dan pada pertemuan II berjumlah 17 orang . Berikut tabel prosentase keaktifan mahasiswa pada siklus II;

Tabel 3. Prosentase Keaktifan Siswa Tindakan Siklus II (\%)

\begin{tabular}{|c|c|c|}
\hline Kelas & Pertemuan I & Pertemuan II \\
\hline D3-BI-IA & $\mathbf{7 5 \%}$ & $\mathbf{9 0 \%}$ \\
\hline D3-BI-IB & $\mathbf{8 0 \%}$ & $\mathbf{8 5 \%}$ \\
\hline
\end{tabular}

\section{Tahap Refleksi}

Dari analisis data kedua siklus tersebut, ternyata peningkatan penguasaan kosa kata Bahasa Inggris melalui penggunaan media lagu sangat efektif. Semua itu disebabkan mahasiswa melakukan pembelajaran terfokus pada kompetensi penguasaan kosa kata dalam prosesnya memperoleh pembelajaran kemampuan terpadu (integrated skill), yaitu mahasiswa dapat melatih listening dengan menyimak lagu, dapat melatih speaking dengan membuat kalimat dan menceritakan kembali, melatih reading dengan membaca teks lagu dan mahasiswa melatih writing dengan menuliskan kata kata saat latihan pada teks yang kosong (cloze procedure).

Peningkatan penguasaan kosa kata tidak hanya diamati selama pembelajaran, tetapi dari hasil prestasi belajar melalui tes penguasaan II. Data yang diperoleh bahwa mahasiswa yang lulus pada kelas D3-BI-IA berjumlah 18 orang atau sebesar $90 \%$ dan kelas D3-BI-IB berjumlah 16 orang atau sebesar $80 \%$. Data ini menunjukkan bahwa adanya peningkatan jumlah kelulusan dari hasil belajar telah mencapai indikator keberhasilan $70 \%$ dari seluruh jumlah mahasiswa dalam satu kelas.

Setelah dilakukan tes, maka tes tersebut dievaluasi melalui program analisis soal. Setelah nilai tiap individu didapat, diberi nilai dan ditabelkan, lalu dimasukkan dalam rumus yang telah terprogram dalam program analisis soal SIMPEL PAS, maka hasil data yang diperoleh dari evaluasi pada tindakan siklus II, sebagai berikut:

1) Hasil Validitas butir $r$ tabel sebesar 0,312 , dengan butir soal yang valid berjumlah 40 butir dan tidak valid berjumlah 10 butir.

2) Hasil Reliabilitas tes sebesar 0,708 (menurut KR-20) dengan kategori reliabilitas tinggi.

3) Hasil Tingkat kesukaran dan Daya Beda diperoleh data 31 soal baik/sangat baik (soal diterima), 7 soal cukup dan 12 soal jelek (soal ditolak).

Hasil penelitian setelah tindakan siklus II dapat dipaparkan sebagai berikut:

1. Penyusunan Satuan Acara Perkuliahan (SAP) tentang penggunaan media lagu untuk membantu peningkatan penguasaan kosa kata Bahasa Inggris siswa pada mata kuliah Vocabulary Building I. Penyusunan SAP telah mencapai indikator yaitu 4 (baik). 
2. Mahasiswa yang aktif selama proses pembelajaran di kelas melebihi indikator keberhasilan 75\%, yaitu pada kelas D3-BI-IA prosentase rata-rata untuk pertemuan I dan II sebesar 82,5\% dan kelas D3-BI-IB sebesar 82,5\% pula. Hal ini berarti ada peningkatan aktivitas pembelajaran sebesar 7,5\% dari indikator keberhasilan.

3. Evaluasi pembelajaran untuk tes telah mencapai indikator keberhasilan.

4. Peningkatan penguasaan kosa kata Bahasa Inggris mahasiswa telah mencapai indikator keberhasilan 60-69\%. Data yang diperoleh bahwa mahasiswa yang tuntas pada kelas D3-BI-IA berjumlah 18 orang atau sebesar 90\% dan kelas D3-BI-IB berjumlah 16 orang atau sebesar $80 \%$.

\section{Pembahasan}

\section{Analisis Tindakan Siklus I dan Siklus II}

Dalam pembelajaran kosakata dengan penggunaan media lagu, mahasiswa dituntut untuk mengaktifkan potensi perbendaharaan kata dan menerima informasi konsep kata yang mungkin belum ada skema kata dalam struktur kognitifnya. Konsep pembelajaran kosa kata Bahasa Inggris dengan penggunaan Jazz Chants merupakan salah satu jurus yang ampuh, dimana pembelajaran akan terasa menyenangkan tanpa tekanan dan beban.

Proses pembelajaran dapat mulai dengan belajar membuka kamus, mencari kata-kata yang asing dan belum dikenali sebelumnya, lalu meng-interpretasikan kata-kata dalam lagu (lyrics) ke dalam kalimat lain atau menceritakan kembali dengan kemampuan kompetensi bahasanya. Peningkatan aktivitas pembelajaran yang diperoleh dari data siklus I dan siklus II digambarkan dalam grafik di bawah ini;

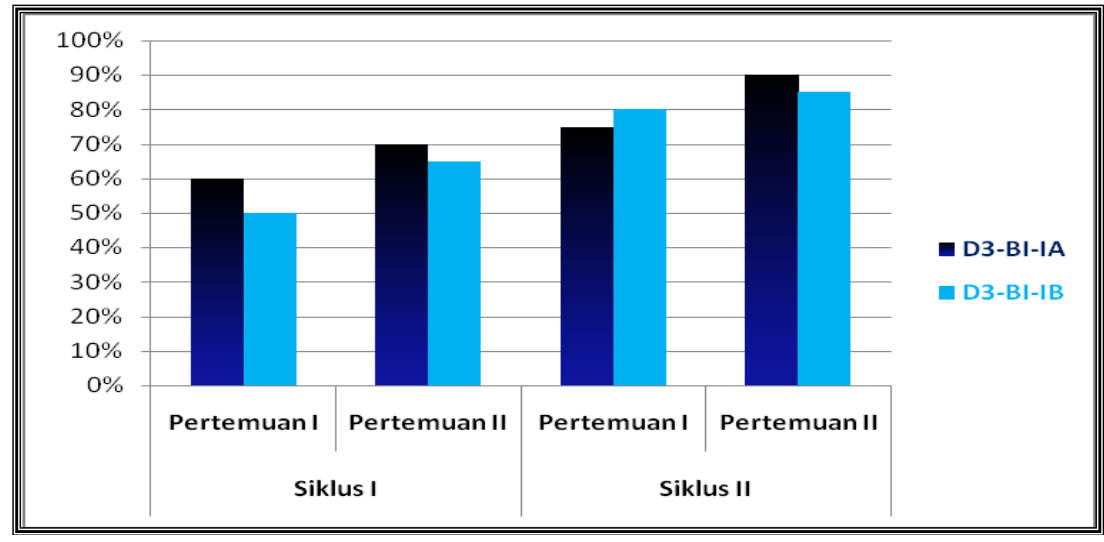

Gambar 1. Grafik Peningkatan Aktivitas Mahasiswa dalam Pembelajaran

Kelebihan tindakan siklus I dan II, sebagai berikut:

a. Pembelajaran bahasa adalah pembelajaran struktur, bunyi, dan kosakata,

b. Drilling menjadi teknik utama pengajaran,

c. Pelafalan seperti penutur asli menjadi tujuan,

d. Sistem bahasa sasaran dipelajari melalui pengajaran nyata tentang pola-pola sistem bahasa tersebut,

e. Kompetensi bahasa menjadi tujuan yang ingin dicapai,

f. Bahasa adalah kebiasaan, sehingga harus sering diulang dalam penggunaan bahasa.

g. Motivasi intrinsic akan timbul dari penggunaan media lagu,

h. Belajar bahasa adalah belajar untuk berkomunikasi. Kompetensi komunikatif menjadi

tujuan yang ingin dicapai, yaitu kemampuan untuk menggunakan bahasa secara efektif dan efisien,

i. Bahasa diperoleh oleh seseorang sering melalui 'trial and error'.

Sedangkan, kelemahan tindakan siklus I dan II, sebagai berikut:

a. Lebih memperhatikan struktur dan bentuk daripada makna,

b. Kegiatan komunikatif dilaksanakan setelah proses panjang drilling dan latihan-latihan, 
c. Penggunaan bahasa ibu dihindari pada tingkat lanjutan,

d. Penerjemahan dihindari pada tingkat-tingkat lanjutan, sehingga terkadang mengaburkan arti kata,

e. Guru sibuk mengawasi siswa dan menjaga agar mereka tidak melakukan kegiatan yang

bertentangan dengan teori pembelajaran.

Hasil proses tindakan ini mengacu pada pernyataan Bolduc dan Fleuret $(2009 ; 3)$ bahwa "one of the best activities for the acquisition of the language is singing". Sehingga para guru dapat memilih dan menyertakan media berbentuk melodi sederhana dengan teks-teks yang berkaitan dengan topik pembelajaran. Campbell (1998: 203) menambahkan "went a step beyond that when he pinpointed that music activates both brain hemispheres, that is, creativity activates the right hemisphere and musical logic does so in the left one". Sehingga kemampuan bahasa siswa dapat berkembang baik dalam kosa-kata, cara pengucapan maupun intonasi dan aksen sesuai dengan bahasa penutur (native speaker).

\section{Analisis Peningkatan Penguasaan Kosa kata Siswa}

Hasil penelitian menunjukkan bahwa penggunaan media lagu berbahasa Inggris dapat meningkatkan kemampuan penguasaan kosakata bahasa Inggris mahasiswa. Peningkatan tersebut terlihat dari perubahan sikap pada proses pembelajarannya dan nilai yang dicapainya pada tiap pertemuan. Perubahan perilakunya meliputi keaktifan, keberanian, kemandirian dan keberhasilan siswa meningkat secara bertahap. Hasil penelitian menunjukkan adanya perubahan cara belajar mahasiswa yaitu mereka lebih bersemangat dalam menerima pelajaran melalui penggunaan media lagu.

Selain peningkatan pada aktivitas belajar, peningkatan penguasaan kosa kata dapat pula diamati dari hasil prestasi belajar mahasiswa melalui tes penguasaan yang diberikan tiap akhir siklus. Peningkatan penguasaan kosa kata mahasiswa disajikan pada grafik di bawah ini:

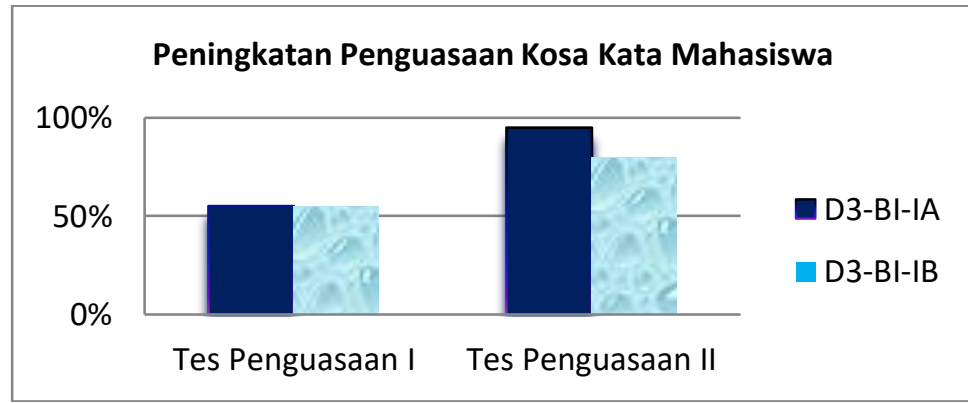

\section{Gambar 2. Grafik Peningkatan Penguasaan Kosa Kata Mahasiswa}

Melalui pembelajaran dengan lingkungan yang dipadukan dengan irama, siswa dapat memusatkan perhatian belajar bahasa berkaitan dengan empat kemampuan yaitu listening, speaking, reading dan wwriting. Hal ini didukung oleh Schellenberg dan Weis (2013) dalam penelitiannya tentang Music and Cognitive Abilities. Hasil penelitian mereka menunjukkan lirik dalam lagu tidak hanya memperkuat penguasaan kosa kata tetapi dapat melatih pemahaman kosakata, kemampuan mendengar, berbicara, membaca dan menulis pula dalam perumusan ritme lagu. Dari penelitian ini menunjukkan belajar bahasa melalui musik dapat diperoleh integrasi pembelajaran, kecerdasan bahasa dan musik dan lingkungan yang positif dan nyaman untuk sikologi pembelajaran.

\section{KESIMPULAN}

Berdasarkan analisis hasil penelitian pada bab IV yang dilaksanakan selama dua siklus dengan penggunaan media lagu untuk meningkatkan penguasaan kosa kata Bahasa Inggris di Akademi Bahasa Asing (ABA) Dian Cipta Cendikia (DCC), maka dapat disimpulkan sebagai berikut: 
1. Proses pembelajaran dapat mengalami peningkatan jumlah mahasiswa yang aktif dalam pembelajaran dari siklus I ke siklus II melalui tahapan pembelajaran sebagai berikut; aktivitas awal (pre-activity), selama kegiatan (while-activity), akhir kegiatan (postactivity). Data yang diperoleh pada siklus I, yaitu jumlah mahasiswa yang aktif selama proses pembelajaran pada kelas D3-BI-IA untuk pertemuan 1 berjumlah 12 orang atau $60 \%$, pada pertemuan 2 berjumlah 14 orang atau 70\%, dan Untuk kelas D3-BI-IB, pada pertemuan 1 berjumlah 10 orang atau $50 \%$ dan pada pertemuan 2 berjumlah 13 orang atau $65 \%$. Sedangkan data yang diperoleh dari siklus II, yaitu untuk kelas D3-BI-IA pada pertemuan 1 berjumlah 15 orang atau 75\%, dan pada pertemuan 2 berjumlah 18 atau $90 \%$. Sedangkan untuk kelas D3-BI-IB pada pertemuan 1 berjumlah 16 orang atau $80 \%$ dan pada pertemuan 2 berjumlah 17 orang atau 85\%. Sehingga diperoleh prosentase rata-rata jumlah keaktifan mahasiswa untuk kedua kelas tersebut sebesar $82,5 \%$, hal ini telah mencapai indikator ketuntasan $75 \%$, maka siklus tindakan dihentikan.

2. Adanya peningkatan penguasaan kosa kata mahasiswa dari hasil prestasi belajar siklus I ke siklus II. Pada siklus I, kelas D3-BI-IA, jumlah mahasiswa yang tuntas sebanyak 11 orang atau 55\%, kelas D3-BI-IB, jumlah mahasiswa yang tuntas sebanyak 11 orang atau 55\%. Sedangkan pada siklus II, kelas D3-BI-IA, jumlah mahasiswa yang tuntas sebanyak 18 orang atau 90\%, kelas D3-BI-IB, jumlah mahasiswa yang tuntas sebanyak 16 orang atau $80 \%$.

\section{DAFTAR PUSTAKA}

Bolduc, J., Fleuret, C. (2009). Placing Music and the centre of literacy Instruction. Association of Deans of Education in Ontario Universities Toronto: Ontario, Literacy and Numeracy Secretariat.

Campbell, Linda, Campbell, Bruce, Dickinsoo, Dee. (1996). Teaching and Learning Through Multiple Intelligences. Allyn and Bacon

Huda, Nuril. 1999. Peningkatan Penguasaan Bahasa Inggris Untuk Menghadapi Globalisasi. Malang : IKIP Malang Publisher.

Medonna, S. (1993). The Effect of Music on Second Language Vocabulary Acquisition. National Network for Early Language Learning, 6(3), 1-8.

Papa, Mario and Lantoro, Giuliano. 1979. Famous British and America Songs andTheir Cultural Background. Singapore : Longman .

Pusporini, R. (2012). Teaching English Genre through Songs. A paper presented at the 59th TEFLIN International Conference. Widya Mandala Catholic University Surabaya. 68 November 2012

Sadiman, Arief. 1993. Media Pendidikan: Pengertian, Pengembangan, dan Pemanfaatan. Jakarta : Grafindo Persada.

Salwa, Ayu Liskinasih. (2016). The Use of Songs in Increasing Students' Understanding of Figurative Language. IJEE (Indonesian Journal of English Education), 3 (1), 2016, 76-88

Schellenberg, E.G. (2005). Music and cognitive ability. Journal of Psychological. University of Toronto.

Yunanto, T., Praptono, F N. 2010. Cara Asik Belajar Bahasa Inggris Lewat lirik Lagu. Jakarta: PT. Tangga Pustaka

Zhang, Jin. 2011. Jazz Chants in English Language Teaching. Theory and Practice in Language Studies, Vol. 1, No. 5. 